\title{
Hegemon wbrew wlasnej woli? Problemy i wyzwania dla przywództwa Niemiec w Unii Europejskiej w drugiej dekadzie XXI wieku ${ }^{1}$
}

\section{Zmiana paradygmatu w polityce europejskiej Niemiec po $1998 \mathrm{r}$.}

Od początków integracji europejskiej w latach pięćdziesiątych XX wieku po schyłek stulecia Niemcy (najpierw Zachodnie i następnie zjednoczone) cele żywotne swojej polityki zagranicznej utożsamiali z budową zjednoczonej Europy. Ofiarność i zaangażowanie opłaciły się. Niemcy w powszechnej opinii uchodziły za lokomotywę integracji europejskiej, a zgoda państw członkowskich EWG na zjednoczenie była dowodem zaufania co do trwałości europejskiej orientacji tego państwa.

Za czasów kanclerstwa H. Kohla Niemcy godziły się na narzuconą im rolę. Zrezygnowały z marki niemieckiej będącej symbolem niemieckiego prestiżu i osiaggniętej prosperity, konsekwentnie realizowały wprowadzanie w życie tzw. trzech filarów traktatu z Maastricht i zabiegały o poszerzenie Unii Europejskiej o nowych członków, chcąc dokończyć dzieła budowy zjednoczonej Europy. Własną politykę zagraniczną i jej cele utożsamiali z polityką europejską. Nie ulega wątpliwości, że przy okazji wykazywali sporo dbałości o własne interesy. Można powiedzieć, że stały się mistrzami w formułowaniu i forsowaniu własnych rozwiązań i postulatów za pomocą pięknie brzmiącej retoryki europejskiej. Przełom nastąpił w 1998 r. kiedy na arenę polityczną wkroczył Gerhard Schröder i pokolenie polityków urodzonych po II wojnie światowej, pozbawionych kompleksów i „kultury wstrzemięźliwości”. Z pewnością musiał nastąpić taki moment w dziejach kontynentu, kiedy Niemcy za wszelką cenę zaczęły domagać się etykiety „normalnego państwa”, posiadającego własne, narodowe interesy. Niemcy szybko zderzyły się z dylematem: w jaki sposób harmonizować narodowy egoizm i europejską solidarność. Jak się wydaje doskonale rozumiał to kanclerz Schröder, który kontynuował dzieło zjednoczenia Europy, ale i w pełni identyfikował się z postrzeganiem Niemiec jak, ,wielkiego mocarstwa" (Grossmacht). Intuicyjnie wyczuwał, że budowa państwa ze stanowczą, samodzielną polityką zagraniczną, potrafiącego stawić opór niekorzystnym dla siebie rozwiązaniom na arenie międzynarodowej, w coraz większym stopniu jest akceptowana przez niemieckie społeczeństwo. Trudno nie oprzeć się stwierdzeniu, że tą filozofią myślenia zapoczątkował erozję niemieckiej polityki europejskiej i jednoznacznej identyfikacji interesów Niemiec z europejskimi. Powstało

1 Artykuł wykonano w ramach projektu badawczego Narodowego Centrum Nauki „Przywództwo Niemiec i Francji w Unii Europejskiej w XXI w. Problemy i wyzwania" UMO-2013/09/B/ HS5/00433. 
wrażenie, że opcja europejska nie jest jedyną orientacją w polityce zagranicznej Niemiec, a ujście dla ich ambicji znajdować się może poza granicami starego kontynentu (Koszel, 2012).

W okresie kanclerstwa G. Schrödera Niemcy miały olbrzymie ambicje, by przyspieszyć rozwój procesów integracyjnych na kontynencie, a kamieniem milowym na drodze do utworzenia nowej formy ustrojowej Unii Europejskiej miała być Konstytucja dla Europy. Debata na ten temat zapoczątkowana została znanym wystapieniem Joschki Fischera 12 maja 2000 r. w auli Uniwersytetu Humboldta w Berlinie, gdzie uzasadnił on konieczność podpisania traktatu konstytucyjnego i przekształcenia UE w federację (B1ätter, 2000, s. 758-761). W przybierającą na siłę debatę na temat przyszłości UE aktywnie zaangażował się prezydent RFN Johannes Rau, a zwłaszcza kanclerz G. Schröder, który zmodyfikował niektóre tezy Fischera i co najważniejsze - przyjął to jako punkt działania rządu. Zjazd niemieckiej socjaldemokracji, który odbył się w dniach 19-22 listopada 2001 r. w Norymberdze uchwalił deklarację, w której m.in. poparto ideę wzmocnienia Parlamentu Europejskiego i Komisji oraz przekształcenie Rady Europejskiej we wspólny rząd (Gloser, 2001, s. 303-207).

Pomimo, że specjalnie zwołany Konwent ds. przyszłości Europy w latach 2002-2003 wypracował projekt traktatu konstytucyjnego, jego przyszłość stanęła pod znakiem zapytania. Otwarcie podpisaniu Eurokonstytucji sprzeciwiła się Wielka Brytania, olbrzymie wątpliwości miała m.in. Polska. Wprawdzie podpisanie tego dokumentu 29 października 2004 na rzymskim Kapitolu kanclerz G. Schröder uznał za sukces, ale było to raczej robienie dobrej miny do złej gry. Traktat konstytucyjny wymagał ratyfikacji przez Parlament Europejski i parlamenty państw członkowskich i z góry wiadomo było, że należy liczyć się z trudnościami. To nie Wielka Brytania jednak - jak przewidywano, lecz Francja (29.05.2005) i Holandia (1.06.2005) u schyłku kadencji niemieckiego przywódcy stały się grabarzami Konstytucji dla Europy w formie wypracowanej przez Konwent, gdyż wyniki głosowania w obu państwach były negatywne (Koszel, 2011, s. 104-105).

Po przejęciu w 2005 r. władzy przez kanclerz Angelę Merkel i koalicję CSU/CDU-SPD hasłem wywoławczym nowego rządu zapisanym w umowie koalicyjnej były „kontynuacja i nowe wyraziste akcenty" (Kontinuität und markante Neuakzentierung) (Gemeinsam, 2005). Oznaczało to dalszą aktywność na rzecz integracji europejskiej, ale w większym niż dotąd stopniu oglądanie się na płynące z niej korzyści. Cechą szczególną tego państwa stała się pokazywana w różnych sferach z coraz to większą stanowczością postawa asertywna, kontestująca bońskie tradycje i otwarta na „nowy patriotyzm".

Priorytetem kanclerz Merkel była reanimacja traktatu konstytucyjnego i celowi temu Niemcy poświęcili wiele energii i zaangażowania. Pomimo, że coraz więcej państw powątpiewało w celowość kontynuowania procesu ratyfikacyjnego, rząd niemiecki z uporem forsował ten projekt. W 2006 r. kanclerz na różnych forach wielokrotnie przekonywała, że konstytucja europejska jest niezwykle potrzebna i leży w interesie obywateli Unii, „czyni Europę bardziej demokratyczną, sprawniejszą i skuteczniejszą w działaniu oraz bardziej przejrzysta" (Europa gelingt gemeinsam, 2007).

Kiedy w pierwszej połowie 2007 r. Niemcy objęły prezydencję w Radzie UE powszechnie oczekiwano, że kanclerz Merkel przezwycięży impas konstytucyjny. Po 
konsultacjach z poszczególnymi państwami szybko okazało się, że Niemcy z determinacją forsujące traktat konstytucyjny znalazły się w ślepej uliczce, gdyż niektóre państwa unijne na czele z Wielką Brytanią i Polską nie chciały słyszeć o Konstytucji dla Europy. W tej sytuacji Merkel skorzystała z pomocy ministra spraw wewnętrznych Francji i od maja 2007 r. prezydenta Nicolasa Sarkozy'ego, który ją przekonał o niecelowości upierania się przy formule konstytucyjnej i zaproponował „traktat uproszczony" (traité simpflié). Na szczycie Rady Europejskiej w czerwcu 2007 r. wieńczącym prezydencję niemiecką przyjęto nowe ustalenia i rozpoczęto prace nad późniejszym Traktatem lizbońskim. Jego zawartość w pełni odpowiadała niemieckim oczekiwaniom, zwłaszcza w procesie podejmowania decyzji w Radzie UE tzw. podwójną większością (Węc, 2011).

\section{Wychodzenie z kryzysu finansowego strefy euro}

Po rozlaniu się kryzysu powstałego w wyniku krachu amerykańskich instytucji finansowych na Europę w 2008 r., rząd niemiecki z dużą rezerwą podchodził do koncepcji wychodzenia z unijną pomocą dla państw południa Europy zagrożonych bankructwem. Niemcy proponowały interwencję zewnętrzną tylko w ostateczności, w konkretnych, poszczególnych wypadkach, gdzie punkt ciężkości położony byłby przede wszystkim na oszczędności, dyscyplinę budżetową i ograniczanie wewnętrznego zadłużenia zagrożonego państwa (Cziomer, 2013, s. 22-23).

Po wielu konsultacjach i akcjach ratunkowych UE i MFW, z których skorzystały Grecja, Portugalia i Irlandia, 30 stycznia 2012 r. na szczycie w Brukseli unijni przywódcy zatwierdzili pakt fiskalny, którego celem było zaostrzenie dyscypliny budżetowej, a tym samym poprawa wiarygodności państw strefy euro wobec rynków finansowych. Gotowość do podpisania paktu wyraziły wszystkie kraje UE oprócz Wielkiej Brytanii oraz Czech, które podtrzymały opinię o konieczności wcześniejszych konsultacji w parlamencie.

Ostatnim akordem intensywnego bliskiego współdziałania pomiędzy Niemcami i Francją było podpisanie 2 marca 2012 r. przez 25 przywódców krajów UE (bez Zjednoczonego Królestwa i Czech) w Brukseli nowego traktatu międzyrządowego określającego zasady wzmacniania dyscypliny finansowej w Unii Europejskiej (Traktat o stabilności, koordynacji i zarzqdzaniu w Unii Gospodarczej $i$ Walutowej). Umowa miała wejść w życie 1 stycznia 2013 roku, przy założeniu, że do tego czasu będzie ratyfikowana przez co najmniej $12 \mathrm{z} 17$ państw strefy euro.

Niemcy okazywali niemałe zadowolenie $z$ osiagnniętego porozumienia, podczas konferencji prasowej kanclerz A. Merkel z naciskiem jednak podkreślała, że pakt stanowi nowy rozdział w przezwyciężaniu kryzysu i poważny krok na drodze do unii stabilizacji, a w dalszej perspektywie zawiera elementy pozwalające przejść w krótkiej perspektywie do unii politycznej. Wyrażała nadzieje, że przyjęte porozumienia będą ściśle respektowane i zwycięży odpowiedzialność. Silnie opowiadała się za pobudzaniem wzrostu w unijnych państwach i nadaniem nowych bodźców gospodarce i nowych impulsów dla wzrostu konkurencyjności europejskich produktów na rynkach światowych (Pressekonferenz von Bundeskanzlerin Merkel, 2012). 
Kanclerz A. Merkel z trudem udało się pozyskać nowego prezydenta Francji Françoisa Hollande'a dla koncepcji unii fiskalnej, który początkowo nie dał jednoznacznej odpowiedzi na pytanie, czy Francja ratyfikuje pakt fiskalny, mocno nalegał natomiast na uruchomienie mechanizmów wzrostu gospodarczego w Unii Europejskiej. Nie chcąc już na początku wchodzić w polityczne zwarcie, Merkel obiecała do czerwca 2012 r. wypracować wspólne propozycje dotyczące polityki wzrostu i zatrudnienia (Weiland, 2012).

Ze względu na fakt, że w końcu czerwca 2012 r. zbliżał się termin ratyfikacji układu, konieczne stało się dla koalicji rządowej wypracowanie kompromisu. W pewnym pośpiechu pomiędzy Urzędem Kanclerskim, Ministerstwem Finansów i Ministerstwem Gospodarki i Auswärtiges Amt uzgodniony został pięciostronicowy dokument „Więcej wzrostu dla Europy: Zatrudnienie - Inwestycje - Innowacje” (Mehr Wachstum für Europa: Beschäftigun - Investitionen - Innovationen). Uwzględniał on wiele postulatów opozycji - socjaldemokratycznej i „Zielonych”, ale nacisk kładł na reformy strukturalne w Unii Europejskiej. 16 czerwca na konwencie partyjnym SPD w Berlinie przyjęto program poparcia paktu fiskalnego pod warunkiem realizacji wcześniej przedstawionych postulatów.

Po partyjnych uzgodnieniach, 29 czerwca Niemcy ratyfikowały pakt fiskalny oraz Europejski Mechanizm Stabilności Finansowej (ESM), jednakże na jego ostateczne wdrożenie przyszło poczekać do 12 września, kiedy po skardze konstytucyjnej w tej sprawie wypowiedział się Federalny Trybunał Konstytucyjny (Bundesverfassungsgericht, 2012).

Zgodnie $\mathrm{z}$ francusko-niemieckimi ustaleniami, rząd A. Merkel wyraził zgodę na uzupełnienie paktu fiskalnego o działania na rzecz wzrostu i zatrudnienia w Unii Europejskiej. 21 czerwca 2012 r. głosami partii reprezentowanych w Bundestagu (poza Die Linke) przyjęta została wspólna deklaracja na zbliżające się obrady Rady Europejskiej. Frakcje parlamentarne domagały się podjęcia różnych działań m.in. opodatkowania banków, wzrost zatrudnienia i inwestycji, uruchomienia programu zapobiegającego bezrobociu wśród młodzieży (Pakt für nachhaltiges Wachstum und Beschäftigung, 2012).

Zastrzeżenia do niemieckich koncepcji oszczędnościowych w przeddzień szczytu zasygnalizowały Włochy i Hiszpania. Rządowi Mariano Rajoy’a zależało na bezpośredniej pomocy państw strefy euro dla ratowania zagrożonych banków (ok. $100 \mathrm{mld}$ euro), ale bez podejmowania działań, które zostały narzucone przez UE i MFW Grecji. Włosi natomiast domagali się stworzenia możliwości lepszej obsługi spłacanych kredytów i umożliwiana zaciagania nowych nisko oprocentowanych kredytów w postaci obligacji europejskich (eurbonds) emitowanych przez EBC. Takie poglądy bliskie były prezydentowi Hollande'owi, który musiał liczyć się z tym, że wpadająca w tarapaty gospodarka francuska również potrzebować będzie zastrzyku finansowego w postaci euroobligacji. Wspólnie zamierzano izolować kanclerz Merkel w Brukseli i aktywnie wziąć udział w „wojnie przeciwko oszczędnościom” (Krauss, 2012).

Kanclerz Merkel nie sprzeciwiała się żądaniom Hiszpanii w kwestii kredytu bankowego, ale postulowane przez Francję emisje euroobligacji traktowała - podobnie jak koła gospodarcze w Niemczech - jako niebezpieczne działania zmierzające w kierunku „Uwspólnotowienia długów” w strefie euro. Wyrażała obawę, że nadmierna ich emisja 
i sprzedaż wywołałaby perturbacje w RFN, która ponosiłaby największe ryzyko jako najsilniejsza gospodarka UE.

22 czerwca na szczycie niemiecko-francusko-włosko-hiszpańskim w Rzymie uzgodniono wsparcie wzrostu gospodarczego w UE sumą 130 mld euro, co miało odpowiadać jednemu procentowi PKB całej UE. Nie było porozumienia w sprawie emisji euroobligacji, które prezydent Hollande uważał za „niezbędny instrument” w walce $\mathrm{z}$ kryzysem i zapowiedział kontynuację prac w tym zakresie (Pressekonferenz Bundeskanzlerin Merkel, 2012).

Na szczycie Rady Europejskiej $28-29$ czerwca 2012 r. zapadły wiążące decyzje i przyjęto Pakt na rzecz wzrostu gospodarczego i zatrudnienia. W konkluzjach ze spotkania z naciskiem podkreślono, że Unia Europejska ma podjąć działania w celu „przywrócenia wzrostu i inwestycji oraz zwiększenia zatrudnienia i europejskiej konkurencyjności”. Obiecywano, że UE „będzie nadal czynić wszystko, co jest konieczne do ponownego wprowadzenia Europy na ścieżkę inteligentnego, trwałego wzrostu gospodarczego sprzyjającego włączeniu społecznemu". Zastrzeżono jednak, że poszerzanie uprawnień państw Eurolandu i UE do ewentualnego korzystania z łatwiejszego dostępu do wspólnotowych gwarancji kredytowych winno jednak zostać połączone w przyszłości ze zobowiązaniami zainteresowanych państw do rygorystycznego przestrzegania paktu fiskalnego oraz ustanowieniem zapowiedzianym na szczycie dodatkowym projekcie utworzenia unii bankowej (Rada Europejska - Konkluzje, Bruksela, 28-29.06.2012; Cziomer, 2012, s. 32).

Zgodnie z zaleceniami Rady Europejskiej, przed kolejnym szczytem UE 18-19 października 2012 r. Komisja Europejska przygotowała raport o realizacji Paktu na rzecz zatrudnienia i wzrostu. Nie przebiła się propozycja ministra W. Schäuble utworzenia urzędu superkomisarza UE, który miałby prawo ingerowania w budżety narodowe państw członkowskich eurolandu w razie stwierdzenia uchybień i nieścisłości finansowych. Swojego poparcia odmówili premier Monti i prezydent Hollande (Monti und Hollande, 2012).

Przed unijnym szczytem 18 października w deklaracji rządowej kanclerz Merkel zapowiedziała liczne działania w kierunku pogłębienia współpracy państw strefy euro. Na liście tej znalazło się zbudowanie wspólnego nadzoru bankowego, forsowana przez 11 państw idea podatku od transakcji finansowych płaconego przez banki, podtrzymanie pomysłu ustanowienia dysponującego szerokimi kompetencjami kontrolnymi komisarza ds. gospodarczo-walutowych, zredukowanie prawa weta państw członkowskich w kwestiach istotnych dla funkcjonowania strefy euro i udzielenie większego demokratycznego mandatu dla instytucji tworzonych w obrębie eurolandu łącznie z powołaniem specjalnych komisji w Parlamencie Europejskim tylko dla posłów pochodzących z obszaru eurolandu. Pomimo wątpliwości, na szczycie w Brukseli prezydent Hollande zaakceptował te propozycje (Regierungserklärung von Bundeskanzlerin Merkel, 2012).

Z pewnością w RFN w 2013 r. istniało przeświadczenie, że dotychczasowe recepty na wyjście z kryzysu i powrót na ścieżkę dynamicznego rozwoju wymagają jednak zdecydowanych, niekonwencjonalnych działań. Nieprzypadkowo już rok wcześniej Niemcy stały się areną niekończących się debat na temat niezbędnych reform w Unii Walutowo-Gospodarczej, przekształceń instytucji unijnych i przyszłości integracji europejskiej. Niemcy, którzy w UE w tym zakresie wyraźnie przejęli inicjatywę w myśl 
propagowanego szeroko hasła mehr Europa na różnych forach europejskich postulowali stopniowe przekształcenie UE w unię polityczną (Księżniakiewicz, 2013).

Jeszcze przed wyborami parlamentarnymi w Niemczech, w sierpniu 2013 r. ukonstytuowała się tzw. Glienicker Gruppe skupiająca 11 wybitnych niemieckich dziennikarzy, ekonomistów i prawników ${ }^{2}$. Pokłosiem dwudniowego spotkania na obrzeżach Berlina w Glienicke stał się swoisty manifest opublikowany już po wyborach i ukonstytuowaniu się nowego rządu w tygodniku „Die Zeit” 25 października 2013 r. Autorzy dokumentu skrytykowali dotychczasowe koncepcje wychodzenia $\mathrm{z}$ kryzysu strefy euro jako niewystarczające. „Pacjent jest chory i aby mu pomóc nie wystarczy zbić gorączkę i zawierzyć siłom odpornościowym organizmu [...] w niemieckim interesie leży, aby przejąć inicjatywę, zamiast chować głowę w piasek". Konkretnie postulowano jak najszybsze wprowadzenie unii bankowej ze sprawnym organem nadzoru finansowego, taką reformę unii walutowej, aby nie dopuścić do tego by jej państwo członkowskie znalazło się u progu upadku, usprawnienie mobilności przepływu siły roboczej w państwach członkowskich, bezwzględne przestrzeganie reguł demokratycznych i państwa prawa, zwiększenie efektywności WPZiB, aby w przyszłości doprowadzić do uzyskania przez UE stałego miejsca w Radzie Bezpieczeństwa ONZ. W ostatniej części podkreślono, że należy de facto pogodzić się z budową Europy różnych prędkości. Wskazano na konieczność podpisania nowego układu państw strefy euro i powołanie sprawnego rządu gospodarczego eurogrupy z własnym budżetem (wkłady $0,5 \%$ PKB rocznie) i prawem ingerencji w finanse krajowe państw członkowskich. Taki rząd byłby wybierany przez specjalny parlament strefy euro (Mobil, gerecht, einig, 2013).

Francja lojalnie wspierała ten pomysł i działania, a prezydent Hollande, choć miał słabszą pozycję w duecie z powodu trudnej sytuacji gospodarczej i słabnącej pozycji w rankingach popularności, próbował wpływać na kierunek tej dyskusji. Paradoksalnie, ale to Niemcy zaczęły przychylać się do starych francuskich koncepcji daleko idącej integracji eurolandu z własnymi instytucjami, budżetem i decydującym głosem w Parlamencie Europejskim. Logika rozwoju wydarzeń wskazuje, że oba państwa pogodzily się $z$ istnieniem dwu-, trzypoziomowej płaszczyzny integracji europejskiej $\mathrm{i}$ trend ten zostanie utrzymany.

Priorytety należały do Unii Bankowej i tutaj, zgodnie z raportem Hermana van Rompuy'a przyjętym na posiedzeniu Rady Europejskiej w grudniu 2012 r., w pierwszej kolejności podjęto działania na rzecz jej ukonstytuowania i urzeczywistnienia. Jej podstawę stanowić miały trzy filary jednolity mechanizm nadzorczy; jednolity mechanizm restrukturyzacji i uporządkowanej likwidacji, a także powiązane ze sobą mechanizmy finansowania (wspólnych dla całego rynku wewnętrznego), czyli jednolity fundusz restrukturyzacji i uporządkowanej likwidacji, system gwarantowania depozytów, wspólny mechanizm ochronny (linia kredytowa) (Węc, 2014, s. 33-34).

Ustrojowe rozwiązania przyjęte dla Unii Bankowej, która wejdzie w życie w $2016 \mathrm{r}$. zapewniają zwłaszcza Niemcom, ale także i Francji, znaczący wpływ na jej funkcjonowanie. Pierwotnie Unia Bankowa miała mieć charakter ponadnarodowy, jednak Niem-

2 Sklad: Armin von Bogdandy, Christian Calliess, Henrik Enderlein, Marcel Fratzscher, Clemens Fuest, Franz C. Mayer, Daniela Schwarzer, Maximilian Steinbeis, Constanze Stelzenmüller, Jakob von Weizsäcker, Guntram Wolff. 
cy wraz z Francją i kilkoma innymi państwami nie zgodziły się na projekt Komisji Europejskiej, co doprowadziło do osłabienia uprawnień tej nowej struktury w Unii Gospodarczej i Walutowej. Ostatecznie postanowiono, że Unia Bankowa będzie strukturą trzy filarową. To głównie pod wpływem rządu Merkel zdecydowano się na określenie zasad funkcjonowania Jednolitego Funduszu Restrukturyzacji i Uporządkowanej Likwidacji w umowie międzyrządowej, a nie w akcie prawa wtórnego. Rząd niemiecki argumentował w czasie negocjacji, że prawo unijne nie daje wystarczającej podstawy prawnej do utworzenia takiego Funduszu, co grozi zakwestionowaniem go w przyszłości przez Federalny Trybunał Konstytucyjny w Karlsruhe.

Pod naciskiem Niemiec opracowane zostały również warunki ustanowienia systemu gwarancji depozytów. Szczegółowe uregulowania zasad funkcjonowania Unii Bankowej zostały uzgodnione pod dużym wpływem rządu niemieckiego. Niemcom udało się obwarować proces restrukturyzacji banków państw strefy euro licznymi zabezpieczeniami, które wzmacniają ich pozycję w procesie podejmowania decyzji, ale także komplikują funkcjonowanie Unii Bankowej (Węc, 2014, s. 43).

Pomimo podejmowanych działań stan i perspektywy dla gospodarki europejskiej trudno było uznać w 2014 r. za zadawalające. Wśród ekonomistów panowała zgoda, że najłatwiej pobudzić gospodarkę poprzez inwestycje w sieci teleinformatyczne, transport i energetykę. Temu celowi służyć miał ogłoszony w końcu listopada $2014 \mathrm{r}$. i uzgodniony z Paryżem i Berlinem plan inwestycyjny nowego przewodniczącego Komisji Europejskiej Jeana-Claude'a Junckera. Projekt ten zasadza się na powołaniu „Europejskiego Funduszu Inwestycji Strategicznych" (EFSI) wartego 21 mld euro, gdzie 5 mld ma pochodzić z Europejskiego Banku Inwestycyjnego (EBI), a pozostałe $16 \mathrm{mld}$ to udział obecnego budżetu UE. $Z$ kolei na te 16 mld euro składać się miało 8 mld euro $z$ budżetu UE, a resztę stanowić mają unijne gwarancje. Dzięki przyciągnięciu prywatnych inwestorów dołączających do projektu Junckera kwota ta miałaby urosnąć do poziomu 315 mld euro (315 Milliarden Euro, 2014).

\section{Osłabienie francusko-niemieckiego motoru integracji}

W latach 2010-2012 bilateralna współpraca francusko-niemiecka zarówno w Unii Europejskiej, jak i na płaszczyźnie dwustronnej uległa zacieśnieniu, a jej głównym spoiwem było wspólne dążenie do przezwyciężenia następstw kryzysu finansowego strefy euro. Powściągliwej i chłodnej kanclerz Angeli Merkel udało się nawiązać dobry kontakt z impulsywnym i hyperaktywnym prezydentem Nicolasem Sarkozy'm. Pod presją wydarzeń, często dochodziło do improwizowanych dwustronnych spotkań Merkel-Sarkozy lub konsultacji w ramach posiedzeń Rady Europejskiej. Na zewnątrz dbano o pozory tak daleko idącej zażyłości, że Sarkozy'ego i Merkel zaczęto uważać za nierozłączną parę i - nieco żartobliwie - określać jako „Merkozy” (Koszel, 2013a, s. $269 \mathrm{i} \mathrm{n.).}$

Jak się tego spodziewano, wybór 6 maja 2012 r. F. Hollande'a na siódmego prezydenta V Republiki spowodował oziębienie relacji francusko-niemieckich. Nowy prezydent w kampanii wyborczej ostro protestował przeciwko oszczędnościowej polityce A. Merkel w strefie euro bez stworzenia mechanizmów pobudzających wzrost gospo- 
darczy i zwiększenia zatrudnienia. Niemiecka prasa wytykała kanclerz Merkel, że preferowała Sarkozy'ego, nie traktowała obu kandydatów w jednakowy sposób i od razu nie zaprosiła Hollande'a do odwiedzin w Berlinie (Brössler, 2012).

Odpowiedź na pytanie o przyszłość współpracy Niemiec i Francji dała już pierwsza zagraniczna wizyta francuskiego prezydenta elekta, złożona jeszcze w dniu jego zaprzysiężenia. 15 maja 2012 r. F. Hollande przybył do Berlina, aby podtrzymać dobrą współpracę obu państw, ale jak sam zaznaczył „,bez ukrywania dzielących ich różnic”. W tym samy duchu brzmiała odpowiedź kanclerz Merkel, która podkreśliła odpowiedzialność Berlina i Paryża za „,dobry rozwój Europy”. Kanclerz w ważnych sprawach europejskich nie zamierzała pójść na rękę Hollande'owi i nie podzielała opinii byłego kanclerza Helmuta Kohla, który miał twierdzić, że będą kanclerzem Niemiec w czasie oficjalnych ceremonii najlepiej jest dwukrotnie ukłonić się przed trójkolorową flagą, aby zaspokoić francuską próżność (Kornelius, 2013, s. 277).

Już w 2012 r. rozpoczęły się zorganizowane na szeroką skalę obchody 50-lecia traktatu elizejskiego. Z okazji 50. rocznicy przemówienia w Ludwigsburgu ówczesnego prezydenta Francji Charles'a de Gaulle’a do niemieckiej młodzieży, 22 września doszło w tym mieście do narady Merkel-Hollande. Paryż i Berlin rozpoczęły tym spotkaniem obchody Niemiecko-Francuskiego Roku. Oboje przywódców po raz kolejny zapowiedziało zwarcie szeregów w celu skuteczniejszej walki z kryzysem w Europie, opowiedzieli się też za ściślejszą współpracą krajów strefy euro (Deutsch-französische Freundschaft, 2012).

Jesienią tego samego roku francusko-niemieckie nieporozumienia na tle dróg wyjścia z kryzysu finansowego strefy euro nasiliły się. Kiedy w listopadzie wizytę w Berlinie złożył nowy premier Jean-Marc Ayrault otwarcie zarzucił gospodarzom ,pouczanie" Francji, która ma sprawdzony model społeczny (sprawiedliwość społeczna), gospodarczy i dobrze wie jakich należy użyć instrumentów, aby przezwyciężyć kryzys. Oceniając na marginesie jego wizyty stan stosunków pomiędzy kanclerz Merkel i prezydentem Hollande'm tygodnik „Der Spiegel” pesymistycznie odnotował: ,właśnie teraz w 50-letnią rocznicę traktatu elizejskiego, który zapoczątkował przyjaźń francusko-niemiecką pojawiła się troska o przyszłość tandemu Berlin-Paryż [...] lewicowy Hollande uważany jest w Berlinie za nieprzeniknionego i dogmatycznego polityka, z kolei w Paryżu Niemka [kanclerz Merkel] ma opinię niesolidarnej i bezkompromisowej „kobiety z marmuru" (Simons, 2012).

Olbrzymie problemy gospodarcze Francji związane z nadmiernym deficytem budżetowym, zadłużeniem wewnętrznym, słabym tempem wzrostu gospodarczego, rosnącym bezrobociem i wzmagającym się od wielu lat spadkiem konkurencyjności francuskich produktów na rynkach światowych poważnie obniżyły notowania prezydenta Hollande'a w rankingach popularności (Monsieur faible), podczas gdy kanclerz Merkel mogła mówić o gospodarczych sukcesach i olbrzymich szansach na zwycięstwo w wyborach w 2013 r (Götz, 2013).

W tej sytuacji na obchodach 50-lecia traktatu elizejskiego w styczniu 2013 r. jakkolwiek zaprogramowanych $\mathrm{z}$ wielkim rozmachem w Berlinie cieniem położyły się problemy finansowe strefy euro $i$ wewnętrzne napięcia $w$ stosunkach francusko-niemieckich. Podczas posiedzenia Bundestagu i Zgromadzenia Narodowego 22 stycznia Hollande i Merkel podkreślali kluczową rolę obu krajów w Europie, zapowiadając pro- 
pozycje pogłębienia unii gospodarczej i walutowej, gdyż jak powiedziała kanclerz „niemiecko-francuska przyjaźń ma kluczowe znaczenie nie tylko dla obu narodów, lecz także dla całej Europy", a oba państwa zawsze pojmowały swoją rolę jako „motor europejskiej integracji”. Hollande zwrócił uwagę, że przyszłość Europy zależy od jakości stosunków niemiecko-francuskich, a przyjaźn między Francuzami i Niemcami ,jest otwarta i nikogo nie wyklucza, lecz chce pociagnąc za sobą całą Europę”. „To właśnie my musimy pokazać, dokąd prowadzi droga" - dodał prezydent Francji. Według Merkel obecny kryzys strefy euro stanowi dla Unii Europejskiej „największe wyzwanie w jej całej historii". Zastrzegała, że oba kraje nie chcą narzucać rozwiązań innym, lecz pracują nad przezwyciężeniem rozbieżnych interesów, by osiagnąc kompromis i przedstawić ofertę, która rozwiąże problem strefy euro i unijnych finansów na siedem lat (Koszel, 2013b, s. 32-33).

W przyjętej przez oba parlamenty 10-punktowej deklaracji zapowiadano wzmocnienie współpracy poszczególnych komisji parlamentarnych i regularne spotkania prezydiów, tworzenie specjalnych wspólnych grup parlamentarnych do zajmowania się konkretnymi kwestiami np. energii, młodzieży czy współpracy gospodarczej. Obiecywano poszerzyć program współpracy szkolnej, nauki języków, wymiany młodzieży i rozciągnąc go na inne państwa. W ostatniej części deklarowano powołanie do życia wspólnych instytutów kultury i przedstawicielstw dyplomatycznych za granicą ( $G e-$ meinsame Erklärung, 2013).

Francusko-niemieckie rozbieżności na tle metod wychodzenia z kryzysu finansowego strefy euro, wzrost popularności Merkel przy stale pogarszających się notowaniach prezydenta Holande' w sondażach nie sprzyjały zacieśnianiu współpracy. 28 marca 2013 r. Hollande oficjalnie przyznał, że pomiędzy Francją i Niemcami istnieje tension amicale i on tego nie zamierza ukrywać. 5 kwietnia dość demonstracyjnie przyjął w Pałacu Elizejskim socjaldemokratycznego kandydata na kanclerza Peera Steinbrücka, co miało być rewanżem za wspieranie przez Merkel Sarkozy'ego w kampanii prezydenckiej we Francji w 2012 r (Le „, tension amicale”, 2013).

Poważne napięcie w stosunkach pomiędzy Paryżem i Berlinem zaistniało po opublikowaniu w czerwcu dokumentu francuskich socjalistów na konferencję partyjną. Padły w nim ostre słowa krytyki pod adresem kanclerz Merkel. Była tam mowa o „egoistycznej, bezkompromisowej" niemieckiej przywódczyni, która myśli wyłącznie o oszczędnościach własnych obywateli i zbliżających się wyborach do Bundestagu. Zakończono mocnym akcentem, że „przyjaźń pomiędzy Francją i Niemcami nie jest przyjaźnią pomiędzy Francją i europejską polityką kanclerz Merkel" (Frankreichs Sozialisten, 2013).

Zgodnie z oczekiwaniami, w wyborach do Bundestagu z 22 września 2013 r. zwycięsko wyszła koalicja CDU/CSU, ale brak liberałów w Bundestagu spowodował odtworzenie „wielkiej koalicji” CSU/CDU-SPD i utrzymanie fotela kanclerskiego przez Merkel. Francuskie media o orientacji prawicowej z uznaniem odnotowały triumf urzędującej kanclerz, ogólnie jednak obawiano się dominującej pozycji kanclerz Merkel w Unii Europejskiej i kontynuowania ,merkiawelizmu” w polityce fiskalnej, przy jednocześnie słabnącej pozycji Francji. Prezydent Hollande po złożeniu gratulacji zaprosił Merkel do Paryża na wspólne konsultacje i obiecał zacieśnienie bilateralnej współpracy. 19 lutego 2014 r. w Paryżu odbyło się specjalne posiedzenie obu rządów poświęco- 
ne w głównym stopniu problemom gospodarczym w strefie euro, zwłaszcza w Grecji i przygotowaniom do utworzenia Unii Bankowej (Talcy, 2014, s. 5-8).

Pomimo wielu istniejących różnic $w$ wielu obszarach unijnej aktywności, obu państwom patronuje hasło: on ne touche pas à l' amitié franco-allemande. Wprawdzie nie ma równowagi w relacjach pomiędzy Berlinem i Paryżem, ale oba państwa wzajemnie się potrzebują. Bliskie współdziałanie na linii Merkel-Hollande ma oddalić posądzenia o hegemonistyczne zapędy Niemiec w Unii Europejskiej. Dla Francji zażyłość z Niemcami ukryć ma wewnętrzne słabości i zachować międzynarodowy prestiż i dumę, które w tym państwie ceni się bardzo wysoko. Wielu polityków i ekspertów uważa jednak, że za słowami o ,świętej przyjaźni” kryją się rutyna, mielizny i brak woli do działania. Już w 2011 r. były ambasador Francji w Berlinie Bernard de Montferrand i historyk Jean-Louis Thiériot w książce France-Allemagne, l'heure de vérite (Paris, 2011), stwierdzili, że ta współpraca musi być kontynuowana, bo po prostu nie ma innego wyjścia.

\section{Kryzys na Ukrainie}

Niepodległa Ukraina nad Renem i Szprewą nigdy nie cieszyła się zainteresowaniem niemieckich polityków i opinii publicznej ze względu na priorytetowe traktowanie stosunków z Rosją. Wprawdzie Niemcy z Ukrainą pod rządami Leonida Krawczuka, Leonida Kuczmy i Wiktora Juszczenki podpisały 15 różnego rodzaju szczegółowych umów, ale nie otworzyło to drzwi do szerszej kooperacji. Zarówno wobec obozu „pomarańczowych", który przejął władzę po 2005 r., jak i w okresie rządów prezydenta Wiktora Janukowycza (od 2010) zachowano chłodny dystans (Księżniakiewicz, 2015).

Przełom nastąpił zimą 2013 r. kiedy po odrzucenia w listopadzie 2013 r. przez prezydenta Janukowycza umowy stowarzyszeniowej z UE doszło do rozpętania krwawych protestów na Majdanie. Wówczas to opinia publiczna w RFN z dużym zainteresowaniem i sympatią odniosła się do tej - jak pisano - „rewolucji godności”. Z dużym ociaganiem, nie kryjąc niechęci, Niemcy podjęły się misji rozjemczej. Dzięki misji Trójkąta Weimarskiego z udzialem ministrów spraw zagranicznych Francji i Polski znaleziono polubowne rozwiązanie. 21 lutego 2014 r. wymuszono porozumienie pomiędzy rządem i opozycją. Zaprzestano rozlewu krwi, prezydent Wiktor Janukowycz zbiegł do Rosji i zapoczątkowano budowę nowego rządu (Doliger, 2014, s. 3-16).

Kiedy na próby uniezależnienia się Ukrainy w Moskwie zareagowano aneksją Krymu i oficjalnym przyłączeniem go do Rosji (18.03.2014), UE i USA zareagowały ostro, zapowiedziały wprowadzenie sankcji ekonomicznych wobec Federacji Rosyjskiej, zawiesiły jej udział w G-8 i wprowadzily zakaz wjazdu na swoje terytorium dla 21 prominentnych działaczy Kremla.

Kanclerz Merkel z niepokojem śledziła wydarzenia na Krymie, ale zachowała zimną krew. Na przemówienie Putina 18 marca oficjalnie włączającego Krym do Rosji zareagowała z dużą powściągliwością i ograniczyła się do stwierdzenia, że jest to naruszenie prawa międzynarodowego. Aprobując sankcje, nie odcięła się od dialogu z Moskwą (Sattar, 2014). Nolens volens, jako że nikt w Europie nie palił się do takich działań, akcji dyplomatycznej podjął się znany z wcześniejszych sympatii do Moskwy Stein- 
meier, który włożył wiele trudu, by uspokoić zaistniałą sytuację. Podróżował do stolic wielu państw, spotykał się z rosyjskim ministrem spraw zagranicznych Siergiejem Ławrowem i w ten sposób wysuwał Niemcy na czoło państw zaangażowanych w rozwiązanie konfliktu na Ukrainie (Wehner, 2014). Nie było to łatwe, ponieważ Niemcy byli wystarczająco zaabsorbowani wychodzeniem z kryzysu strefy euro (budowa unii bankowej), sytuacją w Grecji i paraliżem instytucji unijnych w obliczu zbliżających się wyborów do Parlamentu Europejskiego.

Po dyskusji parlamentarnej w Bundestagu 19 marca 2014 r. postanowiono grać na wszystkich instrumentach, tzn. prowadzić dialog z Moskwą, w razie potrzeby poszerzać sankcje wobec Rosji i kontynuować pomoc finansową dla Ukrainy. Głównym punktem odniesienia było dążenie do zapobieżenia rozprzestrzeniania się kryzysu na wschodnią Ukrainę, stąd też 23 marca pojawiła się niemiecka propozycja wysłania do tego państwa obserwatorów OBWE (Rinke, 2014, s. 33-35).

Przełom w stanowisku Niemiec wobec Rosji ujawnił się po wybuchu inspirowanych przez Moskwę walk we wschodniej Ukrainie (Donbas) i zestrzeleniu w lipcu 2014 r. malezyjskiego samolotu pasażerskiego. Z przeprowadzonych badań wynikało, że $42 \%$ Niemców uważało, że w nowej sytuacji rząd powinien zająć silniejszą pozycję wobec Rosji, natomiast stosunkowo niewielu (18\%) optowało za przyjęciem mniej agresywnej pozycji. Jeden na pięciu badanych stwierdził, że aktualna pozycja rządowa jest właściwa (Nach MH17 - Abschuss, 2014).

Eskalacji konfliktu po wybuchu walk we wschodniej Ukrainie zapobiec miał tzw. format normandzki. Powstał on 6 czerwca 2014 roku, podczas spotkania A. Merkel, F. Hollande'a, Petra Poroszenki i Władimira Putina z okazji kolejnej rocznicy lądowania aliantów w pólnocnej Francji. W ramach formatu normandzkiego powołano tzw. grupę kontaktową Ukraina-Rosja-OBWE, do której zaproszono przedstawicieli tzw. Republik Donieckiej i Ługańskiej. Na początku czerwca grupa uzgodniła zawieszenie broni, które bardzo szybko zakończyło się fiaskiem. W tej sytuacji Niemcy solidarnie opowiedziały się za wprowadzeniem unijnych sankcji wobec Rosji w marcu i we wrześniu 2014 r. W dniach 4-5 września 2014 r. w walijskim Newport odbył się szczyt NATO, gdzie m.in. zadecydowano o uruchomieniu nowych programów mających wzmocnić zdolności sił zbrojnych Ukrainy. 5 września w Mińsku nastąpiło zawarcie pierwszego porozumienia rosyjsko-ukraińskiego, czemu asystowało trzech unijnych komisarzy. Jednakże praktycznie od razu okazało się, że nie jest ono przestrzegane (Meister, 2014).

Zaostrzenie konfliktu we wschodniej Ukrainie jeszcze bardziej przyczyniło się do zwiększenia aktywności europejskich liderów na rzecz znalezienia dyplomatycznego rozwiązania konfliktu na Ukrainie, z A. Merkel w roli głównej. To jej zasługą było doprowadzenie 12 lutego 2015 r. do podpisania tzw. drugiego porozumienia mińskiego, którego głównym punktem było zawieszenie broni i wycofanie ciężkiego sprzętu z linii walk. Negocjacje kosztowały Merkel wiele wysiłków. Odbyła serię rozmów telefonicznych z prezydentem Ukrainy Petro Poroszenka, Putinem i Hollande'm, a z Obamą koordynowała wspólną postawę Zachodu. Podczas lutowej monachijskiej konferencji bezpieczeństwa niezachwianie prezentowała pogląd, że z Rosją trzeba rozmawiać, bo wojna w Donbasie jest dla Ukrainy nie do wygrania (Die Ukraine-Krise, 2015). W Mińsku w czasie wielogodzinnego maratonu groziła zerwaniem rozmów, gdyby se- 
paratyści mieli bojkotować wypracowane ustalenia. Drugie porozumienie mińskie z 12 lutego 2015 r. z pewnością było jej osobistym sukcesem, lecz okupionym fizycznym i psychicznym wyczerpaniem. Udało się jej utrzymać chwiejna jedność państw UE w kwestii utrzymania sankcji wobec Rosji przynajmniej do połowy lipca 2015 r., a we własnym kraju powstrzymać antyukraińską propagandę i skoordynowaną ofensywę „rozumiejących Rosję” (Russlandversteher).

Po 48 godzinach porozumienie mińskie weszło w życie i rozpoczęła się ewakuacja ciężkiego sprzętu z linii frontu. Na wszelki wypadek Merkel dążyła do przedłużenia do końca roku restrykcji nałożonych na Moskwę, co ustawiało ją w roli lidera jastrzębi. Po uzyskaniu akceptacji Francji, na posiedzeniu Rady Europejskiej 19 marca 2015 r. uzależniono kontynuację bądź zawieszenie sankcji od stopnia realizacji przez Moskwę i separatystów ustaleń z Mińska. Ze względu na wielokrotne przypadki łamania przez separatystów tych porozumień, 22 czerwca ministrowie spraw zagranicznych UE jednomyślnie zadecydowali o przedłużeniu sankcji do 31 stycznia $2016 \mathrm{r}$.

W większości niemieckich opinii wypowiadanych przez specjalistów i ekspertów, Ukraina powinna pogodzić się z utratą dwóch separatystycznych prowincji, bo alternatywą będzie pogłębienie chaosu i rozpad państwa. Rosja przyjęła strategię na długofalowe osłabianie Ukrainy, licząc na jej wewnętrzne podziały. Jak pisał znany analityk i znawca spraw rosyjskich z berlińskiego Instytutu Badawczego DGAP Stefan Meister „Iluzjąjest przeświadczenie - że z obecnym rosyjskim kierownictwem uda się wypracować jakikolwiek kompromis. Konflikt z Unią Europejską i Zachodem stabilizuje reżim Putina" (Meister, 2015). Jednocześnie postuluje się, aby Unia Europejska dokładnie sprecyzowała swoje zamiary wobec „nowej” Ukrainy i traktatowo nakreśliła dokładnie jej europejskie perspektywy. Sama A. Merkel wobec Ukrainy nie ma większych złudzeń. Ma świadomość, że jest to państwo przeżarte korupcją z oligarchiczną gospodarka, głębokimi podziałami kulturowymi i ciagotami do wybujałego nacjonalizmu. Usprawiedliwiane wojną reformy wprowadzane są opieszale, powierzchownie, a wśród społeczeństwa nie ma gotowości do dalszych wyrzeczeń. Na gruncie niemieckich doświadczeń historycznych, nie mogła przejść jednak do porządku dziennego nad jawnym łamaniem i naruszaniem integralności terytorialnej jakiegokolwiek państwa europejskiego.

\section{Grexit i Brexit}

Powstanie nowego rządu A. Merkel jesienią 2009 r. tym razem już w koalicji z liberałami zbiegło się z wybuchem kryzysu greckiego. W październiku 2009 r. grecki minister finansów Giorgos Papakonstantinou poinformował o zwiększeniu zadłużenia państwa, co pogłębiło nieufność rynków finansowych do tego kraju i niechęć do zakupu greckich obligacji. Zakup papierów greckich pomimo wysokiego oprocentowania był tak ryzykowny, że nie kwapiono się z ich nabywaniem. W kolejnych miesiącach tak obniżona została wiarygodność kredytowa Grecji, że jej obligacje określano mianem „Śmieciowych” (Krakowski, 2011, s. 31).

W tej sytuacji oczy europejskiej opinii publicznej skierowane zostały na Niemcy. Finansowe wsparcie dla Grecji nigdy nie stało w Berlinie pod znakiem zapytania - nie 
tylko z obawy o stabilność euro, lecz także ze względu na narodowy interes. Bankructwo Grecji uderzyłoby w pierwszym rzędzie w niemieckie banki, które zakupiły greckie obligacje na sumę 33,9 mld euro. Transfer miliardów euro do zagrożonej Grecji nie był kwestionowany, ale pod warunkiem, że państwo to zaaplikuje sobie drakońską kurację oszczędnościową, przestanie żyć na kredyt i pogłębiać dług publiczny. Kanclerz Merkel miała jednak świadomość, że transfer niemieckich pieniędzy na południe nie wzbudzi zachwytu niemieckich podatników, zwłaszcza w obliczu seryjnie odbywających się wyborów do parlamentów krajowych (Stempin, 2014, s. 335).

Po posiedzeniu Rady Europejskiej w dniach 25-26 marca 2010 r. w następnych miesiącach ruszyła skoordynowana akcja państw strefy euro i MFW, co zaowocowało uruchamianiem kolejnych transz pomocy finansowej dla Grecji z olbrzymiego pakietu finansowego w wysokości 110 mld euro. Pieniądze w pierwszej kolejności przeznaczone były na wsparcie banków krajowych, ustabilizowanie budżetu i powstrzymanie załamania gospodarczego. W zamian Grecja zobowiązała się do ambitnego, trudnego programu reform i cięć budżetowych, który zakładał ograniczenie deficytu finansów publicznych poniżej 3\% PKB do roku 2014.

W kwietniu 2011 r. rząd grecki pod presją Komisji Europejskiej ogłosił przyjęcie ostrego kursu na oszczędności w wydatkach państwa, a 10 czerwca 2011 r. niemiecki Bundestag uchwalił nowy pakiet pomocowy dla Grecji obwarowany jednakże twardymi warunkami. Ateny miały dokonać głębokiej prywatyzacji majątku państwowego i utrzymać oszczędnościowy kurs w polityce finansowej. Minister finansów W. Schäuble domagał się udziału w akcji ratunkowej prywatnych wierzycieli, przede wszystkim banków komercyjnych, które hojną ręką udzielały Grecji pożyczek i kupowały greckie obligacje, orientując się w opłakanym stanie finansów tego państwa (Hildebrandt, 2011).

W drugiej połowie maja 2011 roku sytuacja finansowa Grecji skomplikowała się. 23 maja w Atenach podjęto decyzję o następnych oszczędnościach. Miały one dotyczyć kolejnego obniżenia zarobków pracowników administracji państwowej, zmniejszenia ich liczby oraz podwyższenia podatków. Premier Jeorjos Papandreu wierzył, że dzięki nowym oszczędnościom poprawi sceptyczne analizy Europejskiego Banku Centralnego i rynków finansowych. W tym samym czasie kredytujące zadłużoną Grecję kraje strefy euro coraz mocniej naciskały na to, by oprócz pakietu oszczędnościowego Ateny przyspieszyły spłacanie swoich zobowiązań poprzez prywatyzację. 24 maja 2011 roku grecki minister finansów Giorgos Papakonstantinu zapowiedział, że jeśli jego kraj nie otrzyma do końca lipca kolejnej transzy pomocy w wysokości $17 \mathrm{mld}$ euro, to ogłosi niewypłacalność (Górniewicz, 2014, s. 43).

W zaistniałej sytuacji grożącej niewypłacalnością Aten, szczyt Unii Europejskiej w Brukseli 23-24 czerwca przyjął nowe zobowiązania wobec tego państwa, tym bardziej, że premier J. Papandreu uzyskał w parlamencie votum zaufania i przyrzekł kontynuację surowych reform oszczędnościowych. Uzgodniono, że dodatkowe środki dla Grecji „będą finansowane ze źródeł publicznych, jak i prywatnych”. Oznaczało to nowy pakiet finansowy państw strefy euro i MFW w wysokości 109 mld euro. Po raz pierwszy uczestniczyć w nim miały banki komercyjne, fundusze emerytalne i instytucje ubezpieczeniowe na sumę $37 \mathrm{mld}$ euro. Rada Europejska zaapelowała do Grecji o ,jedność narodową" i poparcie wszystkich sił politycznych „w celu zapewnienia rygorystycznej i sprawnej realizacji reform" (Rada Europejska, 2011). 
Przyjęcie przez parlament grecki 29 czerwca reform oszczędnościowych spowodowało, że 2 lipca ministrowie finansów strefy euro uruchomili transfer do Grecji $12 \mathrm{mld}$ euro pochodzących jeszcze z pierwszego pakietu pomocowego na załatanie najpilniejszych potrzeb.

Pomimo, że podanie kolejnej tratwy ratunkowej Grecji odbijało się negatywnie na wynikach CDU w wyborach do landtagów, kanclerz Merkel 7 września 2011 r. w Bundestagu przestrzegła deputowanych, że ,jeśli upadnie euro, upadnie Europa”. Podkreśliła, iż „euro nie może upaść, nie może i nie upadnie, o ile pójdziemy długą i trudną drogą. Ale jest to droga właściwa" - zapewniała. I przekonywała, że opanowanie tego kryzysu to zadanie dla obecnego pokolenia. Werbowała zwolenników mówiąc, że przyszłość Niemiec ,jest nierozerwalnie związana z przyszłością Europy”, a Europa „oznacza wiele, znacznie więcej niż wspólna waluta”. Zapowiedziała oszczędności i atakowała przy tym poprzedni rząd SPD i Zielonych, który nie potrafił zreformować finansów publicznych i wbrew zdaniu ekspertów zgodził się, by Grecja weszła do strefy euro (Generaldebatte, 2011).

W końcu września 2011 r. Niemcy wzmogli naciski na Grecję, aby ta kontynuowała zdecydowanie dzieło naprawy finansów państwa, gdyż od tego zależeć będzie dopływ pieniędzy do jej gospodarki w postaci kolejnej transzy pomocy. Jednocześnie działając w napięciu i atmosferze pewnej nerwowości kanclerz Merkel zmuszona była do pacyfikacji opornych polityków i posłów we własnych szeregach partii Unii i koalicyjnej FDP, której przywódca i zarazem wicekanclerz, minister gospodarki i technologii Philipp Rösler otwarcie mówił o konieczności dopuszczenia do bankructwa Grecji (Philipp Rösler, 2011).

Zanim pierwszy pakiet pomocy się wyczerpał, Grecja otrzymała w lutym $2012 \mathrm{r}$. drugi pakiet obejmujacy kwotę 130 mld euro. Pożyczki były nisko oprocentowane, a ich spłata rozłożona na 30 lat (do 2054). Prywatni właściciele obligacji zostali nakłonieni do wydłużenia terminu spłaty, obniżenia oprocentowania i zaakceptowania łącznie 53,5\% strat $\mathrm{w}$ stosunku do wartości nominalnej obligacji.

W roku wyborów parlamentarnych do Bundestagu kanclerz Merkel miała świadomość, że wskutek społecznego oporu program oszczędnościowy rządu greckiego praktycznie nie daje efektów, a drakońska kuracja zaaplikowana temu państwu pod presją Berlina tylko pobudza antyniemieckie nastroje na ulicach greckich miast. W tej sytuacji kanclerz musiała umiejętnie lawirować. W kampanii wyborczej w Niemczech, by nie zrażać do siebie obywateli, pokazywała twarde oblicze „Frau Germanii” - nieustępliwość i troskę o pieniądze niemieckich podatników, ale na zewnątrz wielokrotnie powtarzała znaną wypowiedź, że ,euro nie może upaść” i dawała do zrozumienia, że w 2014 r. bierze pod uwagę udzielenie kolejnej pomocy finansowej Grecji.

Rok 2015 stał się dla Grecji najtrudniejszy. Jej zadłużenie urosło do niebotycznego pułapu 320 mld euro, z czego $220 \mathrm{mld}$ stanowiły dwa znane pakiety pomocowe. Spłaty tylko w tym roku wynieść miały ogółem 22,3 mld euro. Można to było uczynić tylko w ścisłym porozumieniu z ,trojką" - Europejskim Bankiem Centralnym, Międzynarodowym Funduszem Walutowym i Komisją Europejską i spłacać stare długi poprzez zaciąganie nowych, co zresztą było powszechną praktyką bankową. Jednakże program reform został zahamowany. Zadłużenie wewnętrzne do 2013 rosło zamiast maleć, rozmyły się plany prywatyzacji, gdyż zamiast planowanych 50 mld euro z tego tytułu 
osiagnięto zaledwie 3,2 mld. Kraj popadł w głęboką recesję, deficyt budżetowy w $2013 \mathrm{r}$. osiagnął 8,7\% (Gadomski, 2015).

Nic dziwnego, że w wyborach parlamentarnych w styczniu 2015 r. zwyciężyła lewicowa, populistyczna SYRIZA, a premierem został deklarujący walkę z brukselskim dyktatem Alexis Tsipras. Pogłębiła się niechęć do Niemiec, od których zaczęto ponownie domagać się spłaty reparacji wojennych za szkody wyrządzone przez niemiecki reżim okupacyjny w latach 1941-1944. Symbolem greckiej nienawiści stał się pokazywany w nazistowskim mundurze minister $\mathrm{W}$. Schäuble jak uważano zaprzysięgły wróg jakikolwiek ustępstw wobec Aten (Schäuble, 2015).

Jak się spodziewano, w Niemczech z dużą niechęcią przyjęto - jak pisano w prasie - rządy nieobliczalnej SYRIZY. Szef działu zagranicznego opiniotwórczej „Frankfurter Allgemeine Zeitung" Klaus-Dieter Frankeneberger bez ogródek pisał, że nowy rząd „marnuje cenny czas na polityczne błazeństwa i szantaże wspierane antyniemieckimi resentymentami" (Frankenberger, 2015).

Od lutego rząd A. Tsiprasa negocjował z ,trojką" na temat złagodzenia warunków, które Grecja musiałaby spełnić, aby otrzymać od eurogrupy 7,2 mld euro - za pomocą których uregulowałaby swoje zobowiązania wobec MFW. Premier Grecji twierdził, że narzucone przez instytucje „,trojki” zaciskanie pasa ma katastrofalne skutki dla greckiego społeczeństwa i gospodarki. Kredytodawcy Aten odrzucili propozycje złagodzenia warunków pomocy.

Wizyta nowego premiera Grecji A. Tsiprasa w Berlinie w marcu 2015 r. nie przyniosła żadnego przełomu. Pomimo utyskiwań premiera, że Grecja znajduje się na progu wytrzymałości, Niemcy zapowiedzieli dokładne przyjrzenie się przez eurogrupę programowi reform rządu SYRIZY. Powtarzali, że liczyć się będą tylko reformy strukturalne, solidnie skonstruowany budżet i sprawnie funkcjonująca administracja (Schäfers, 2015). Jednocześnie $w$ Niemczech nasiliły się głosy polityków i ekspertów opowiadających się za kontrolowanym wyjściem Grecji ze strefy euro (Grexit) jako najlepszym rozwiązaniem. Znany ekonomista, dyrektor monachijskiego renomowanego Instytutu Badań Nad Gospodarką Hans Werner Sinn nawoływał do zamiany przez Grecję euro na drachmy co miałoby przynieść wzmocnienie konkurencyjności gospodarki greckiej. Za czołowego orędownika takiego rozwiązania uchodził też minister Schäuble, który nie wykluczał możliwości opuszczenia przez Grecję strefy euro na 4-5 lat i późniejszy powrót tego państwa do wspólnej waluty (Siedenbiedel, 2015; Bannas, 2015).

W końcu czerwca 2015 r. Grecja oświadczyła, że nie jest w stanie spłacić wartej 1,6 mld euro raty na rzecz MFW a 30 czerwca wygasła umowa, którą Grecja zawarła z Europejskim Instrumentem Stabilności Finansowej. Jednocześnie premier Tsipras zapowiedział na 5 lipca rozpisanie referendum w kwestii porozumienia z międzynarodowymi wierzycielami. Wobec takiego zwrotu sytuacji, kanclerz Merkel 29 czerwca w pilnym trybie zwołała zebranie liderów partii tworzących jej rząd-CDU, CSU i SPD oraz partii opozycyjnych reprezentowanych w Bundestagu - Lewicy i Zielonych. W spotkaniu wzięli także udział szefowie klubów parlamentarnych tych ugrupowań. Po spotkaniu stwierdziła, że po stronie greckiej nie było woli do kompromisu, co uwidoczniło się w przerwaniu negocjacji i decyzji o referendum, ale jeśli po referendum rząd grecki poprosi o wznowienie negocjacji, to Niemcy nie wniosą sprzeciwu (Merkel, 2015). 
Nie było tajemnica, że greckie referendum miało być środkiem nacisku na eurogrupę, by rozpocząć negocjacje na nowych lepszych dla Grecji warunkach. Po jego korzystnym dla rządu wyniku (61,31\% przeciwko warunkom zagranicznej pomocy i $38,69 \%$ na tak) premier Tsipras zapowiedział, że przedstawi nowy wniosek o pomoc finansową z Europejskiego Mechanizmu Stabilności. Po francusko-niemieckich konsultacjach w Paryżu, 7 lipca po szczycie państw strefy euro przewodniczący Rady Europejskiej Donald Tusk potwierdził, że organy strefy są gotowe podjąć wszelkie działania, by zapewnić Grecji stabilność finansową. Kolejne spotkanie 12 lipca dało zielone światło do dalszych negocjacji finansowych, ale przedstawiono listę twardych warunków, które miały być uchwalone przez grecki parlament jako warunek wstępny. $\mathrm{Na}$ liście widniały m.in. żądania usprawnienia systemu VAT i poszerzenie bazy podatkowej, by zwiększyć dochody, stabilność systemu emerytalnego w ramach całościowego programu reform emerytalnych, reformy w sądownictwie i bankowości, czy zapewnienie pełnej niezależności prawnej urzędu statystycznego ELSTAT (Oświadczenie, 2015).

Kiedy rząd w Atenach zaaprobował warunki, 17 lipca doszło do głosowania w Bundestagu nad pełnomocnictwami dla gabinetu w sprawie kontynuowania akcji pomocowej dla Grecji i trzeciego pakietu ratunkowego. Kanclerz wygrała przekonująco: na 598 oddanych głosów, jej politykę wsparło 439 deputowanych, ale wśród głosujących na „nie” (119) znalazło się aż 60 spośród posłów z jej macierzystej partii CDU (Bundestag stimmt, 2015).

20 lipca Grecja otrzymała pilną pożyczkę w wysokości 7,16 mld euro, co pozwoliło jej na spłacenie zaległości wobec MFW i należnej raty do Europejskiego Banku Centralnego. Środki pochodzily ze wspólnego dla całej UE Europejskiego Mechanizmu Stabilizacji Finansowej (EFSM) - na jego wykorzystanie musiały się zgodzić także kraje spoza strefy euro. 23 lipca parlament grecki z dużymi oporami przyjął pakiet reform, co pozwoliło uruchomić negocjacje nad trzyletnim programem wsparcia tego kraju, ocenianym na 86 mld euro.

Niemcy mogli mieć powody do zadowolenia z takiego rozwoju sytuacji, gdyż oddaliła się perspektywa Grexitu. Mieli oni też najwięcej do stracenia. W wyniku finansowego załamania się Grecji utraciłyby ok. 65 mld euro. Doszłoby do destabilizacji strefy euro i zawirowań na międzynarodowym rynku finansowym. Kryzys mógłby dotknąć Hiszpanię i Portugalię i - w reakcji łańcuchowej - ostatecznie Francję, co oznaczałoby koniec strefy euro. Liczyły się też argumenty polityczne. Grecja pod rządami Tsiprasa zasugerowała jako alternatywę dla UE zbliżenie z Rosją, która ma w Brukseli od kilku lat najgorsze notowania. Grecja liczy się jako partner do walki z nielegalną imigracja, jest ważnym członkiem NATO strzegącym jej wschodniej flanki na Morzu Śródziemnym. I wreszcie Grexit podważyłby spójność i zwartość całej Unii Europejskiej, co dla Niemców nie byłoby do przyjęcia (Sattar, 2015).

Zupełnie inny wymiar miało podejście Niemców do perspektywy wystąpienia Wielkiej Brytanii z Unii Europejskiej (Brexit). Konserwatyści brytyjscy, którzy pod wodzą Edwarda Heatha wprowadzili Zjednoczone Królestwo w 1973 r. do EWG, w następnych latach (M. Thatcher, J. Major) należeli do największych krytyków pogkębienia integracji europejskiej. Wielka Brytania nie stała się członkiem unii walutowo-gospodarczej, choć bez przeszkód wypełniła kryteria konwergencji. Po dziesięciu latach 
rządów Tony Blaira i Partii Pracy w wyniku zwycięstwa wyborczego w 2010 r. torysi ponownie objęli władzę (wespół z liberałami), a premierem został eurosceptyczny David Cameron (Liddle, 2014). Już na szczycie Rady Europejskiej 8-9 grudnia 2011 r. kiedy zapadła decyzja o przyjęciu paktu fiskalnego, Cameron swoją zgodę na zmianę unijnych traktatów uzależnił od specjalnych gwarancji dających Londynowi prawo do nietykalności ich usług finansowych. Taka postawa wywołała w Niemczech powszechną krytykę, gdyż uważano, że Cameron rozbija europejską solidarność w trudnym okresie próby. W najbardziej skrajnych opiniach domagano się usunięcia Brytyjczyków z Unii Europejskiej, ponieważ hamują proces integracji i budowę zjednoczonej Europy (Brüsseler Beschlüsse, 2011).

W przemówieniu z 23 stycznia 2013 r. premier Cameron po raz pierwszy zasygnalizował możliwość opuszczenia UE przez Wielką Brytanię i poddanie tej kwestii $\mathrm{w}$ referendum. Skrytykował eurobiurokracje, skostnienie unijnych instytucji oraz funkcjonowanie strefy euro, domagał się większej konkurencyjności na rynkach i innowacyjności. Za konieczne uważał zmiany unijnych traktatów (David Cameron's EU speech, 2013).

Cameron pod naciskami eurosceptycznego skrzydła we własnej Partii Konserwatywnej oraz pod wpływem wzrostu popularności antyunijnej Partii Niepodległości Zjednoczonego Królestwa (UKIP) obiecał, że doprowadzi do renegocjacji warunków brytyjskiego członkostwa w UE i wymusi ustępstwa na rzecz Londynu.

Po wyborach parlamentarnych 8 maja 2015 r. kiedy konserwatyści zdobyli większość w parlamencie i samodzielne rządy, Cameron z odnowionym mandatem zaczął naciskać na liderów unijnych, by ci zgodzili się na reformę traktatów. W przeciwnym razie do $2017 \mathrm{r}$. na Wyspach zostanie rozpisane referendum $\mathrm{w}$ sprawie pozostania Wielkiej Brytanii w UE. Szefowie instytucji unijnych powtarzali jednak, że są gotowi wyjść naprzeciw oczekiwaniom Wielkiej Brytanii, ale odrzucają możliwość negocjacji dotyczących fundamentalnych swobód w UE, a zwłaszcza zasady swobodnego przepływu osób. Z pewnością sytuacja premiera byla trudna. Aby zadowolić eurosceptyków we własnych szeregach musiałby domagać się radykalnej rewizji unijnych traktatów, na co wśród unijnych partnerów nie było zgody. Znany niemiecki publicysta wydawca i redaktor naczelny tygodnika „Die Zeit” Theo Sommer, określił to jako kwadraturę koła, z której trudno będzie się Cameronowi wyplątać (Sommer, 2015).

Niemcy z dużym dystansem i pragmatycznie podchodzili do enuncjacji brytyjskiego premiera traktując to w pierwszej kolejności jako element wewnętrznej walki politycznej i środek presji na Brukselę. Mieli świadomość odrębnej pozycji Zjednoczonego Królestwa w UE i tego, że nigdy w dziejach integracji europejskiej nie było ono jej kołem zamachowym. Podzielali sporą część brytyjskich zastrzeżeń dotyczącą nadmiernej omnipotencji unijnych instytucji, funkcjonowania konkurencyjności i konieczności wzmocnienia zasady subsydiarności. Kanclerz Merkel uważała, że możliwy jest kompromis, łącznie ze zmianę traktatów (Spengler, 2015).

W maju 2015 r. premier Cameron odbył podróże do Holandii, Francji, Polski i Niemiec, przekonując do poparcia swych planów dotyczących zmian w funkcjonowaniu UE. 29 maja po spotkaniu w Berlinie ustalono, że możliwe jest rozpoczęcie negocjacji nad zmianą traktatów, ale Niemcy dali wyraźnie do zrozumienia, że nie wyrażą zgody, na rozwiązania, które podważałyby sens istnienia Jednolitego Rynku Wewnętrznego - kręgosłupa UE. W pelni podzielali opinie premiera co do nadużywania przez zatrud- 
nionych w bogatych krajach UE świadczeń socjalnych, niezbędności reformy polityki imigracyjnej i konieczności nowych regulacji na rynku pracy (Cameron, 2015).

Niemcom, podobnie jak pozostałym państwom unijnym, zależy na dalszej obecności Brytyjczyków w UE. Orientują się, że koszty „Brexitu” byłyby wysokie. Wielka Brytania jest trzecim co wielkości unijnym państwem (12,5\% unijnej populacji), wnoszącym $14 \%$ całego unijnego PKB. Gdyby Brytyjczycy opuścili UE zachwiany zostałby jej rynek wewnętrzny, gdyż należałoby wprowadzić cła. Oznaczałoby to straty dla niemieckiego eksportu, ponieważ w 2014 r. Wielka Brytania była trzecim co do wielkości po USA i Francją odbiorcą niemieckich towarów (84,1 mld euro). Pojawiłyby się trudności z przepływem kapitału, który dotąd w dużym stopniu obsługiwało londyńskie City. UE utraciłaby potęgę atomową, co osłabiłoby Wspólną Politykę Zagraniczną i Bezpieczeństwa. Zmniejszyłaby się ranga i pozycja UE w świecie (Möller, Olive, 2014).

\section{6. „Europejskie Niemcy w germańskiej Europie”}

Ta przewrotna teza znanego niemieckiego socjologa U1richa Becka z 2013 r. dobrze oddaje dyskusje, jaka od dłuższego czasu toczy się w publicznej debacie na temat przywództwa niemieckiego w Unii Europejskiej w XXI wieku. Już od początku lat dziewięćdziesiątych obawiano się zjednoczonych Niemiec i ich potegi gospodarczej, ale jednocześnie dominowało przeświadczenie, że nową uzyskaną siłę Niemcy spożytkują na rzecz budowy zjednoczonej Europy. Na wszelki wypadek pogłębiono integrację europejską w postaci traktatu z Maastricht. Miał on uwikłać Niemcy w kokonie konstrukcji europejskiej do takiego stopnia, aby nie były w stanie podjąć żadnej poważniejszej inicjatywy bez aprobaty ich sojuszników i partnerów. Pozbawienie Niemców marki niemieckiej, która była symbolem niemieckiego prestiżu i osiągniętej prosperity i wprowadzenie wspólnej waluty miało być jednym $z$ instrumentów tej polityki i gwarancja , ,europeizacji” Niemiec.

Swiatowy kryzys gospodarczy w 2008 r. i jego rozlanie się na Europę spowodowały, że Niemcy jako najważniejsze państwo eurolandu stały się centrum polityki europejskiej. Kanclerz Merkel zasmakowała w polityce zagranicznej i coraz pewniej poruszała się na europejskich i światowych salonach. Niezachwianie przekonywała, że w swojej działalności kieruje się przesłaniem in dubio pro Europa, ale jej działaniom przyglądano się z coraz większą podejrzliwością. Jak pisała w 2013 r. Gertrud Höhler, autorka głośnej, krytycznej wobec Merkel książki „Im gorsza była sytuacja Europy, tym lepiej powodziło się Niemcom [...] Europa sięgnąwszy dna była gotowa na przyjęcie koncepcji władzy Merkel, a Merkel szykowała się do rządzenia Europa" (Höhler, 2013, s. 115-116). Wspomniany U. Beck wskazywał na pozorną apolityczność działań niemieckich przysłanianych wyłączną troską o stan unijnych finansów i równowage budżetowa. „Nowa niemiecka władza w Europie nie opiera się jak niegdysiejszych czasach na przemocy, ale na ultima ratio. Nie potrzebuje broni, by innym państwom narzucić swoją wolę" (Beck, 2013, s. 69). Wyglądało więc na to, że przywództwo w Europie nie spadło na Berlin nieoczekiwanie, ale też uzewnętrzniło, że nie do końca dają oni sobie z tym radę. Wprawdzie imponuje im prestiż i ranga mocarstwa, na którego zwrócone są oczy Europy i innych wielkich światowych potęg, ale z drugiej strony mają 
świadomość, że w realiach XXI w. dominacja w Europie oznacza w pierwszej kolejności olbrzymią odpowiedzialność i poważne finansowe obciążenia. Znany badacz spraw niemieckich z uniwersytetu w Birmingham William Paterson używa określenia „niechciany" hegemon (reluctant hegemon), co można jednakowoż rozumieć dwuznacznie. $Z$ jednej strony jako niechęć samych Niemców do sprawowania przywódczej roli w Europie, a z drugiej jako rezerwa ich sąsiadów i partnerów wobec dominującej roli tego państwa w Europie. Brytyjski badacz wymienia trzy poważne ograniczenia, z którymi muszą liczyć się Niemcy w swoich wielkomocarstwowych aspiracjach: ograniczenie ich potęgi do sfery gospodarczej, z powodu ich przeszłości brak międzynarodowej akceptacji i legitymizacji do sprawowania roli hegemona i wreszcie ograniczenia wewnętrzne w postaci ścisłej kontroli przez Bundestag polityki zagranicznej rządu, wspieranego autorytetem Federalnego Trybunału Konstytucyjnego (Paterson, 2010).

Sami Niemcy z dużą niechęcią mówią o własnym przywództwie w UE i starają się uciszyć groźne pomruki płynące z południa Europy o powstawaniu zaborczej IV Rzeszy (Feltri e Sangiuliano, 2014). Ceniony politolog starszej generacji Christian Hacke już w 1988 r. pisał, że Niemcy są „,hegemonem wbrew własnej woli” (Hegemon wider Willen) i powtórzył to zdanie w książce wydanej już po zjednoczeniu, w kilka lat później (Hacke, 1988, 1993).

Niemcy są silne w Europie, ale wynika to ze słabości ich partnerów. Potrafiły narzucić i tak zarządzać kryzysem strefy euro, aby to najlepiej odpowiadało ich interesom. Są też największym beneficjentem Unii Walutowo-Gospodarczej (Meyer, Watt, 2014). Ostatnie decyzje EBC o masowym wykupie obligacji państw członkowskich UE w Niemczech podniosły euforię, bo w dalszej perspektywie oznaczać to będzie ożywienie unijnej gospodarki w UE, wzrost inflacji w strefie euro i osłabienie kursu tej waluty na giełdach międzynarodowych. Jeżeli dodać do tego niskie ceny surowców energetycznych to oznaczać będzie olbrzymie możliwości dla niemieckich eksporterów i wzrost sprzedaży niemieckich produktów nie tylko na rynkach światowych, ale przede wszystkim w UE napędzanej nową koniunkturą i pakietem Junckera. Dziennik „Die Welt" nazwał to ,słodkim prezentem dla Niemiec" (Eigendorf, 2015). Ale w opinii Günthera Oettingera byłego premiera kraju Badenii-Wirtembergii i obecnego komisarza Unii Europejskiej wygłoszonej na początku 2015 r. Niemcy jeszcze jak nigdy dotąd nie były tak silne, ale silniejsze już nie będą. Podziwiane przez wszystkich rosnące świadczenia socjalne $\mathrm{w}$ tym kraju i oszałamiające wyniki w eksporcie nie będą trwały dhugo. Niemcy dramatycznie się starzeją, a mieszkańcy USA są przeciętnie o 7 lat młodsi od obywateli RFN. Są syci i zadowoleni z osiagnniętego poziomu życia i pragną utrzymania status quo. Z ich strony nie należy oczekiwać żadnego poważnego impulsu dla integracji europejskiej (Scholz, 2105).

\section{Bibliografia}

315 Milliarden Euro: Junckers Mega-Investitionsplan wird noch etwas größer (2014), „Der Spiegel” z 26.11 .

Bannas G. (2015), Weniger Griechenland, mehr Europa, „Frankfurter Allgemeine Zeitung” z 15.07. 
Beck U. (2013), Niemiecka Europa, Wyd. Naukowe PWN, Warszawa.

„Blätter für deutsche und internatonale Politik”, 2000, nr 6.

Brössler D. (2012), Stimmen zur französischen Präsidentschaftswahl. Wie Deutschland auf Hollande reagiert, „Süddeutsche Zeitung” z 6.05 .

Brüsseler Beschlüsse: „Anfang vom Ende der britischen EU-Mitgliedschaft” (2011), „Die Welt” z 11.12 .

Bundestag stimmt für Verhandlungen über drittes Hilfspaket (2015), „Die Zeit” z 17.07.

Bundesverfassungsgericht weist Eilanträge gegen ESM und Fiskalpakt zurïck - Ratifizierung kann jetzt zügig umgesetzt werden, Bundesministerium der Finanzen, http://www.bundesfinanzministerium.de/Content/DE/Pressemitteilungen/Finanzpolitik /2012/09/2012-09-12-PM50.html.

Cameron-Besuch in Berlin: Merkel kann sich Vertragsänderungen für London vorstellen (2015), „Der Spiegel” z 29.05.

Cziomer E. (2012), Wyzwania kryzysu zadluzenia strefy euro dla poszukiwania nowej roli Niemiec w Unii Europejskiej w XX wieku, „Rocznik Integracji Europejskiej”, nr 6.

Cziomer E. (2013), Rola Niemiec w kryzysie strefy euro po 2009, Oficyna Wydawnicza AFM, Kraków.

David Cameron's EU speech (2013), "The Guardian" z 23.01.

Deutsch-französische Freundschaft ,Wir bilden das Herz Europas” (2012), „Frankfurter Allgemeine Zeitung" z 22.09.

Didzoleit W., Aust S., Koch D. (1999), Uns die Last erleichtern. Bundeskanzler Gerhard Schröder über seine Einstellung zu Europa, über die deutsche Präsidentschaft und die Erweiterung der $E U$, ,Der Spiegel” z 4.01.

Die Ukraine-Krise im Fokus der Münchener Sicherheitskonferenz 2015 (2015), „Ukraine Analysen”, nr 145, www. laender-analysen.de/ukraine.

Doliger Ph. (2014), Le Triangle de Weimar à l'épreuve de la crise ukrainienne, „Allemagne d'aujourd'hui', $\mathrm{nr} 209$.

Eigendorf J. (2015), Wir Deutschen müssen raus aus dem Schlaraffenland, „Die Welt” z 25.01.

Europa gelingt gemeinsam, „Präsidentschaftsprogramm”, 1 Januar-30 Juni 2007, http://www.auswaertiges-amt.de/diplo/de/EU-P/EU-P.html;por.

Feltri V., e Sangiuliano G. (2014), Il Quarto Reich. Come la Germania ha sottomesso l'Europa, Wyd. Mondadori, Milano.

Frankenberger K.-D. (2015), Schluss mit den Clownerien, „Frankfurter Allgemeine Zeitung” z 23.03.

Frankreichs Sozialisten: Front gegen Merkel (2013), „Der Spiegel” z 27.04.

Gadomski W. (2015), Jak splonęto 30 mld euro, „Gazeta Wyborcza” z 11-12.07.

Gemeinsam für Deutschland - mit Mut und Menschlichkeit. Koalitionsvertrag zwischen CDU, CSU und SPD, Berlin 11.11.2005, http://www.kas.de/upload/ACDP/CDU/Koalitionsvertraege/ Koalitionsvertrag2005.pdf.

Gemeinsame Erklärung von Deutschem Bundestag und Assemblée nationale aus Anlass des 50. Jahrestags der Unterzeichnung des Élysée-Vertrages, http://www.bundestag.de/dokumente/ textarchiv/2013/425557672kw04elyseeerklaerung/index.html.

Generaldebatte im Bundestag: „Scheitert der Euro, scheitert Europa” (2011), „Frankfurter Allgemeine Zeitung" z 7.09 .

Gloser G. (2001), Die europäische integration Voranbringen: zum europäischen Leitantrag der SPD, „Integration", nr 3.

Gốtz M. (2013), Partnerstwo czy nierównowaga? Francja wobec rosnacej pozycji Niemiec w Unii Europejskiej, „Biuletyn Instytutu Zachodniego”, nr 128. 
Górniewicz G. (2014), Kryzys finansów publicznych Grecji, „Studia z zakresu prawa administracji i zarzadzania UKW", t. 6.

Hacke Ch. $(1988,1993)$, Weltmacht wider Willen. Die Außenpolitik der Bundesrepublik Deutschland. Wyd. Clett-Kotta, Wyd. Ullstein, Stuttgart-Frankfurt/M.

Hildebrand J. (2011), Merkel und Schäuble werben für weiteres Hilfspaket, „Die Welt” z 8.06.

Höhler G. (2013), Matka chrzestna. Jak Merkel przebudowuje Niemcy, Wyd. Zyska i Ska, Poznań.

Kornelius S. (2013), Pani kanclerz Angela Merkel, Wyd. FILIA, Poznań.

Koszel B. (2011), Rola zjednoczonych Niemiec w procesie integracji europejskiej, w: Polityka zagraniczna zjednoczonych Niemiec, red. J. Kiwerska, B. Koszel, S. Żerko, Wyd. Instytutu Zachodniego, Poznań.

Koszel B. (2012), Mocarstwowe aspiracje Niemiec w Europie XXI wieku: realia i perspektywy, „IZ Policy Papers", nr 6.

Koszel B. (2013a), Nierówne partnerstwo? Niemcy i Francja w Unii Europejskiej (1933-2013), Wyd. PWSZ, Piła.

Koszel B. (2013b), Merkollande? Partnerstwo Francji i Niemiec w Unii Europejskiej $w$ okresie rządów prezydenta Françoisa Hollande'a, „Rocznik Integracji Europejskiej”, nr 7.

Krakowski J. (2011), Kryzys finansowy świata zachodniego i kryzys euro, „Sprawy Międzynarodowe", $\mathrm{nr} 2$.

Krauss M. (2012), Hollande und Monti verprellen Merkel, „Financial Times Deutschland” z 6.06.

Księżniakiewicz M. (2013), Niemiecka debata nad przyszlościa integracji europejskiej (po traktacie z Maastricht), „Przegląd Zachodni”, nr 2.

Księżniakiewicz M. (2015), Niechciany partner Rola Niemiec w rozwiazywaniu konfliktu na Ukrainie, „Biuletyn Niemiecki”, nr 57, http://fwpn.org.pl/assets/Publikacje/Biuletyn_Niemiecki/ 2015/BIULETYN_NIEMIECKI_NR_57.pdf.

Le ,tension amicale” à „égod'sme”, les mots de la gauche face à Angela Merkel (2013) „L'Express” z 29.04.

Liddle R. (2014), The Europe dilemma. Britain and the Drama of EU Integration, IB. Tauris \&Co.Ltd., London.

Meister S. (2014), Putin richtig verstehen, „DGAPstandpunkt”, no 6, September, https://dgap.org/ de/article/getFullPDF/25882.

Meister S. (2015), Politik der Illusionen. Ein Ausgleich mit Russland auf Grundlage einer EU-EWU-Partnerschaft ist irrig, https://zeitschrift-ip.dgap.org/de/article/getFullPDF/26490.

Merkel gegen Einigung ,, um jeden Preis” (2015), „Franzkfurter Allgemeine Zeitung” z 2.07.

Meyer H., Watt A. (2014), Die 10 Mythen der Eurokrise und warum sie falsch sind, http:/www.boeckler.de/pdf/imk_10_mythen.pdf.

Mobil, gerecht, einig (2013), „Die Zeit” z 25.10.

Möller A., Olive T. (2014), The United Kingdom and the European Union: What would a „Brexit" mean for the EU and other States around the World?, „DGAPanalyse", September, https://dgap.org/de/article/getFullPDF/25764.

Monti und Hollande sind gegen einen ,S Superkommissar” (2012), „Handelsblatt” z 19.06.

Nach MH17 - Abschuss: Forderungen nach Handelssanktionen gegen Russland weiter gestiegen (2014), https:/yougov.de/news/2014/07/23/nach-mh17-abschuss-forderungen-nach-handelssanktio/.

Oświadczenie szczytu państw strefy euro Bruksela, 12 lipca 2015 r, file://C:/Documents\%20and\%20Settings/ Komputer/Moje\%20dokumenty/Downloads/20150712-eurosummit-statement-greece_PL.pdf. 
Pakt für nach haltiges Wachstum und Beschäftigung. Gemeinsames Papier der Bundesregierung und der Fraktionen CDU/CSU, FDP, SPD und Bündnis 90/Die Grünen im Deutschen Bundestag, Pressemitteilung, Presse- und Informationsamt der Bundesregierung Nr. 212/12 vom 21. Juni 2012.

Paterson W. (2010), The Reluctant Hegemon? Germany Moves Centre Stage in the European Union. "The JCMS Annual Rieview of the European Union in 2010".

Philipp Rösler: Vizekanzler bringt Staatspleite Griechenlands ins Spiel (2011), „Die Welt” z 11.09.

Pressekonferenz Bundeskanzlerin Merkel, italienischer MP Monti, französischer StP Hollande und spanischer MP Rajoy, Mitschrift Pressekonferenz, 22.06.2012, Die Bundesregierung. http://www.bundesregierung.de/Content/DE/Mitschrift/Pressekonferenzen/2012/06/2012-0622-vierertreffen-rom.html.

Pressekonferenz von Bundeskanzlerin Merkel zu den Ergebnissen des Europäischen Rates am 1./2. März in Brüssel, http://www.bundesregierung.de/Content/DE/Mitschrift/Pressekonferenzen/2012/ 03/2012-03-02-eu-ratbkin.html;jsessionid=F458A5386E89610086C5F39441F36975.s2t2?nn= 28588\& site $=$ Nachhaltigkeit.

Rada Europejska 23-24 czerwca 2011 roku. Konkluzje, http:/www.consilium.europa.eu/uedocs/ cms_data/docs/pressdata/PL/ec/123087.pdf.

Rada Europejska 25-26 marca 2010. Konkluzje, http:/www.consilium.europa.eu/uedocs/cms_data/ docs/pressdata/PL/ec/113605.pdf.

Rada Europejska. Konkluzje, 28-29 marca 2012, http://www.consilium.europa.eu/uedocs/cms_data/ docs/pressdata/PL/ec/131395.pdf.

Regierungserklärung von Bundeskanzlerin Merkel zum Europäischen Rat am 18. und 19. Oktober 2012 in Brüssel, Die Bundesregierung, http:/www.bundesregierung.de/Content/DE/Regierungs-erklaerung/2012/2012-10-18-merkel.html.

Rinke A. (2014), Wie Putin Berlin verlor Moskaus Anexion der Krim hat die deutsche Russland-Politik verändert, „Internationale Politik”, $\mathrm{nr} 5$.

Sattar M. (2014), Wohl oder übel. Deutsche Reaktion auf Krim-Annexion, „Frankfurter Allgemeine Zeitung" z 18.03.

Sattar M. (2015), Die Rückkehr der Geopolitik. Die Gefahren eines Grexit sind heute eher politischer Art, „Internationale Politik” nr 3.

Schäfers M. (2015), Weder sind die Griechen Faulenzer, noch sind die Deutschen schuld, „Frankfurter Allgemeine Zeitung" z 23.03.

Schäuble W. (2015), Schäuble über Tsipras-Regierung: „Sie haben alles Vertrauen zerstört”, „Der Spiegel" z 17.03 .

Scholz S. (2015), Kein Grund zum Zurücklehnen, http://www.schwaebisch.de/wirtschaft/ aktuelle-nachvinten_artikel-KeinGrund-zumzuruecklehnen-_arid,10157920.html.

Schröder G. (2002), Rede von Bundeskanzler Gerhard Schröder zum Wahlkampfauftakt am Montag, 5. August 2002, in Hannover, http://www.spd.de/servlet/PB/show/1019520/Schr\%F6der\% 20Rede \%20Wahlkampf-auftaktHannover.doc.

Siedenbiedel Ch. (2015), Der Grexit ist die Rettung, „Frankfurter Allgemeine Zeitung” z 22.06.

Simons S. (2012), Frankreichs Premier Ayrault in Berlin: Deutschstunde, „Der Spiegel” z 15.11.

Sommer Th. (2015), Cameron muss konkret werden, „Die Zeit” z 5.06.

Spengler J. (2015), Wie sich die britischen EU-Hasser kaltstellen lassen, „Handelsblatt” z 29.05.

Stempin A. (2014), Angela Merkel. Cesarzowa Europy, Wyd. Agora, Warszawa.

Talcy F. (2014), Dans l'attente des décisions, „Dokumente, Zeitschrift für den deutsch französischen Dialog", nr 2. 
Traynor I. (2011), As the dust settles, a cold new Europe with Germany in charge will emerge, „The Guardian" z 9.12.

Wehner M. (2014), Steinmeiers große Illusion, „Frankfurter Allgemeine Zeitung” z 15.03.

Weiland S. (2012), Handschlag statt Küsschen, „Der Spiegel” z 15.05.

Węc J. J. (2011), Traktat lizboński. Polityczne aspekty reformy ustrojowej Unii Europejskiej w latach 2007-2009, Księgarnia Akademicka, Kraków.

Węc J. J. (2014), Proces konstytuowania Unii Bankowej. Geneza, podstawy prawne, cele i zasady dziatania, „Rocznik Integracji Europejskiej”, nr 8.

\section{Streszczenie}

W artykule autor analizuje główne problemy związane z przywództwem Niemiec w UE w drugiej dekadzie XXI w. Zaliczył do nich kryzys finansowy strefy euro, osłabienie francusko-niemieckiego motoru integracji europejskiej, kryzys na Ukrainie oraz perspektywy Grexitu i Brexitu. Wskazuje, że Niemcy jakkolwiek dość niechętnie wykorzystują pomyślną dla nich koniunkturę i wysunęły się na pozycję niekwestionowanego lidera w Unii Europejskiej.

Slowa kluczowe: Unia Europejska, Niemcy, hegemonia w Europie

\section{A hegemony against its own will? The problems and challenges facing German leadership in the European Union in the 2010s}

\section{Summary}

In the paper the author analyses the main issues related to the leadership of Germany in the EU in the 2010s. Among them are the financial crisis in the euro zone, the weakening of the Franco-German engine of European integration, the crisis in Ukraine and the prospects for Grexit and Brexit. He indicates that the Germans, although quite reluctantly, are taking advantage of an economic situation which is favourable for them and have taken the position of unquestionable leader in the European Union.

Key words: European Union, Germany, hegemony in Europe 
